\title{
Bibliometric Survey for Adoption of Building Information Modeling (BIM) in Construction Industry- A Safety Perspective
}

\author{
Shalaka Hire ${ }^{1} \cdot$ Sayali Sandbhor ${ }^{1} \cdot$ Kirti Ruikar $^{2}$
}

Received: 16 September 2020 / Accepted: 3 April 2021 / Published online: 17 May 2021

(c) The Author(s) 2021

\begin{abstract}
The construction industry is multidisciplinary in nature and various operations are executed at the same time. One of the major resources for executing construction operations is the human workforce. Management of this workforce with effective safety provisions is a prime factor for reducing accidents on construction sites. Nowadays, technologies such as Building Information Modeling (BIM) offer the potential to manage safety on-site with their automatic safety checking capability. $\mathrm{BIM}$ is a model-based smart $\mathrm{nD}$ platform that offers tools for architecture, engineering, and construction proficients to plan, design, and manage construction activities more efficiently. Despite its growing use globally, BIM has not been adopted sufficiently in the Indian construction industry. This paper presents a bibliometric analysis of the adoption of BIM in the global construction and the Indian construction industry. It also reviews the adoption of BIM for safety in the global and Indian construction industry. The bibliometric analysis is carried out in two phases, at first it reviews the adoption of BIM globally, and limits the findings to cover BIM adoption in the Indian construction industry. Secondly, it reviews the adoption of BIM for safety in global construction and limits the findings to cover BIM adoption for safety in India. Various complementary tools such as VOSviewer, iMapbuilder have been used for data analysis. The research highlights the need for BIM in India particularly for safety on construction sites.
\end{abstract}

\section{Introduction}

The construction industry is one of the largest industries. As per the 12th Five-year plan (2012-2017) given by the Planning Commission of India, its contribution to nations' GDP is approximately $8 \%$ [1]. A construction project involves numerous operations which are carried out on sites at the same time. These operations could not be performed smoothly if there is no proper management system. The adoption of several technologies for effective and efficient management of work is not new in the construction

Sayali Sandbhor

sayali.sandbhor@sitpune.edu.in

Shalaka Hire

shalaka.hire@sitpune.edu.in

Kirti Ruikar

K.D.Ruikar@lboro.ac.uk

1 Civil Engineering Department, Symbiosis Institute of Technology (SIT), Symbiosis International (Deemed University) (SIU), Pune, Maharashtra, India

2 School of Architecture, Building and Civil Engineering, Loughborough University, Loughborough, UK industry. Building Information Modeling (BIM) has the potential to help organizations to manage their work efficiently. BIM applications span over the entire lifecycle of a facility. BIM has its applications in the various phases of construction such as programming, design, pre-construction, construction, and post-construction phase (operations and maintenance) [2, 3]. Along with these applications, BIM is also referred to as computational BIM to the innovative problem-solving approach where users define algorithms to have automated generation and manipulation of buildingrelated information for better work efficiency, effectiveness, and productivity gains.BIM is defined as, "a systematic process for managing and disseminating holistic information generated throughout the development and operation of building design" [4]. They further elucidate the existence of different context-dependent definitions of BIM. These concepts essentially define the exchange, analysis, and use of meta-data surrounding a CAD model to serve multiple functions for different stakeholders in a construction and operations cycle [5]. Autodesk emphasizes the 'Intelligent' 3D model-based process dimension that gives Architecture, Engineering, and Construction (AEC) professionals' insight and tools to plan, design, develop and manage buildings and 
infrastructure more efficiently. BIM is stated as a new paradigm in the thriving sustainable construction industry [6]. BIM is a process that involves the use of various tools with various functionalities. Examples of modeling tools used in BIM include Revit, ArchiCAD, Vectorworks, and Bricscad, among others. For clash analysis, Navisworks, BIMSight, Solibri Model Checker are available [7]. Although most drawings can be prepared using traditional CAD software, BIM software produces drawings more efficiently because of the ability to use parametric data, which maps changes at all times and retains consistency [8]. BIM also has the potential for developing an environment that adopts computational design for the early design stages [9]. A comparison between "Traditional" and "BIM" Process is explored [2] as shown in Fig. 1. The primary difference between BIM and conventional 3D CAD technology is that the latter portrays a building with individual 3D views such as plans, sections, and elevations. Unlike 3D CAD, BIM is not simply geometric representations, but a complex virtual repository of real 'models' and lifecycle knowledge contained within parametric data/information attached to the model.

Successful BIM implementation requires the early participation of all project stakeholders. This means that conventional project management systems (e.g. design-bid-build) play a very limited role in projects focused on BIM. Some of the major applications of BIM comprises of quantity collection and estimation, clash detection and coordination, stakeholder integration and collaboration, and last but not least design and visualization [10]. Drivers for BIM adoption, stating top BIM drivers as clash detection, government drive, competitive edge, accurate construction sequencing, cost savings through reduced re-work [11]. According to Eastman et al. (2011), building models are characterized by:

- Building components are represented with 1) digital representations (objects) carrying computable graphics and data attributes identifying them to software applications,

and 2) parametric rules allowing intelligent manipulation;

- Components that include data describing how they operate as required for analysis and work processes. For example, quantity takeoff, specification, and analysis of the energy;

- Reliable and non-redundant data such as modifications of the component data are reflected in all views of the component and the assemblies of which it is a party; and

- Coordinated data to represent all model views in a coordinated manner.

As a result of this inherent capability, the intelligence embedded in the BIM objects allows for context-specific 'behavioral' information to be associated with the 'represented' object. Thus, even if there is a change to one characteristic of an object or a family of objects (e.g. a wall in a plan), the change is reflected in every other instance of that object or family. For example, changes are reflected in the quantities of bricks in the wall, the specifications, the geometries, and among other changes those to the other 'associated' drawings, where the wall is housed (e.g. the elevations, sections, details). BIM has various dimensions and an associated set of functionalities contained within each dimension (Fig. 2). These dimensions emphasize specific capabilities. For instance, 3D represents the 'visualization' capability of BIM, whereas $4 \mathrm{D}$, represents the ability to program a set of time-bound activities of construction projects. Currently, $\mathrm{BIM}$ has incorporated functionalities ranging from levels 3D to $8 \mathrm{D}$.

Starting from 3D, it is the most familiar dimension of spatial representation of the project. Next is 4D BIM, consisting of a time model that adds an extra information aspect to a project information model in the form of timing data. 5D provides in real-time all cost-data, including cost budgeting, cost control, and also life cycle cost analysis [13]. Integrating BIM with 5D CAD simulation models allows for

\section{'BIM' Process}

'Traditional' Process

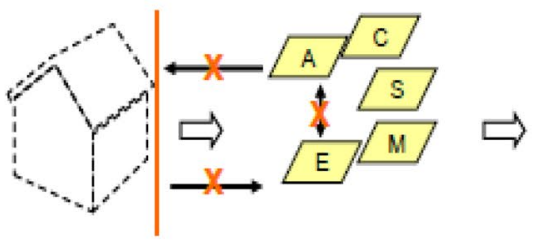

Concept \& Design

Documents \& Drawings

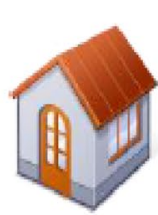

Construction \& Operation

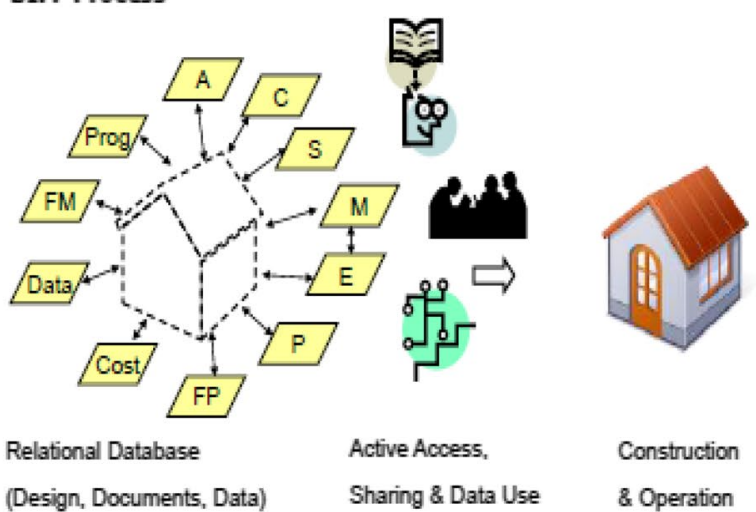

Fig. 1 A contrast of "Traditional" process with "BIM" process Source: [4] 

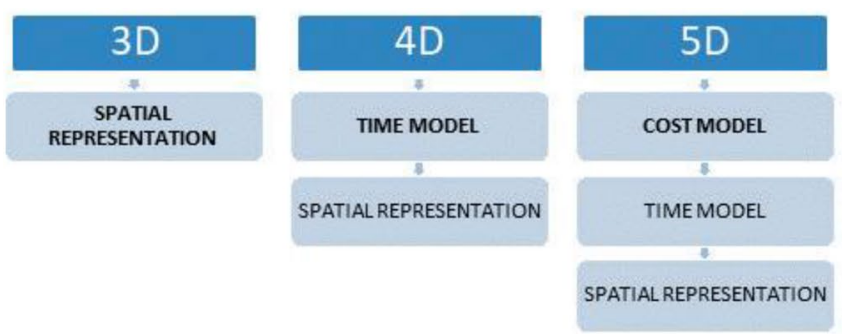

Fig. 2 Dimensions of BIM Source: [14]

more efficient, cost-effective, and sustainable building development. 6th dimension concerns the assessment of energy consumptions. 7D represents the facility management model to control and sustain the entire life-cycle of the enterprise. The last 8 th dimension is about security at the project site to assess the risks of operators and avoid critical hazardous scenarios [12]. The development of functionalities through dimensions is growing from $3 \mathrm{D}$ to $\mathrm{nD}$. Considering safety, the 8th dimension is associated with safety, where BIM model can identify risk-prone areas followed by the development of a model for automated safety checking using the integration of BIM and safety rules. GPS is also integrated with BIM, to track the position of workers and prevent hazards. It can be stated that BIM has been leading towards a more intelligent and smart process through its dimensions. Computational BIM is an innovative problem-solving approach that can be used for simplifying and mimicking the real scenario. It involves designing algorithms to have automated creation and use of information for improved design effectiveness and productivity benefitting from virtual programming and modeling. This intelligent model-based process provides a framework for correlating and impacting the building design data. Algorithmic BIM is a design paradigm that merges the potentialities of both algorithmic design and $\mathrm{BIM}$ and integrates it into the design workflow to develop a model critically relying on mathematical knowledge [14]. AEC industry is moving towards applying artificial intelligence and machine learning in their workflows. It is necessitating the creation of structured, good quality data within the information models and project environments to leverage computational algorithms for improving the design and delivery process in AEC. Information modeling augmented with computational techniques models the performance of the project throughout all the phases of its life cycle. Computational BIM can be clubbed together with safety rules for effective safety management by modeling the data for
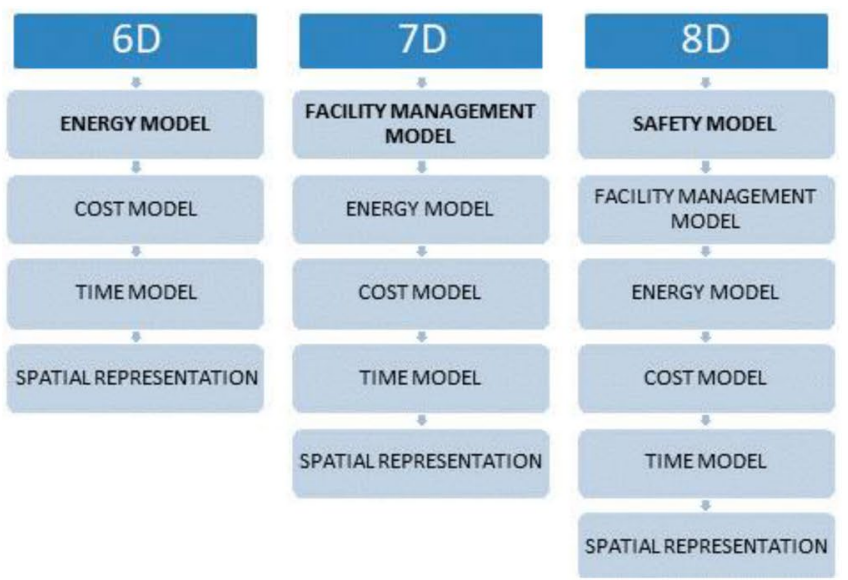

computing the possibility of hazards and visualizing it in the virtual environment.

\subsection{Global Trends in BIM Adoption}

BIM is rapidly gaining global prominence. Its potential benefits for various lifecycle processes are well documented in global literature by Eastman et al. and [15-17]. BIM awareness is nearly universal, though worldwide adoption is still ongoing and inconsistent [18]. The state of global adoption of BIM for 2017 was explored in one of the researches [19]. The data showed that various countries are at different stages of BIM adoption in 2017. From Fig. 3 it is observed that at the mature end of the scale, open BIM standards (Austria and Norway) are evident, along with a BIM mandate (in 13 countries), while at the other end there are those (such as Brazil, Italy, Czech Republic, New Zealand, Switzerland, and Belgium) who are planning on BIM adoption (Fig. 3). India is not present at any level in this study which was carried out in 2017.

\section{Need of Study}

Various activities are involved in a typical construction project. These include activities such as excavation, formwork, concreting, brickwork, slab formwork, finishing, and many more. Due to the various activities that need to be completed within a fixed schedule and budget, there is a need for an appropriate management system for all these activities. These activities are performed by various stakeholders at different stages of the project's lifecycle. Conventional paper-based methods of managing schedules, budgets, activities, designs, are plagued with inefficiencies. These practices are conventionally silo-based, lacking a whole-lifecycle perspective, where the transfer of information is typically 


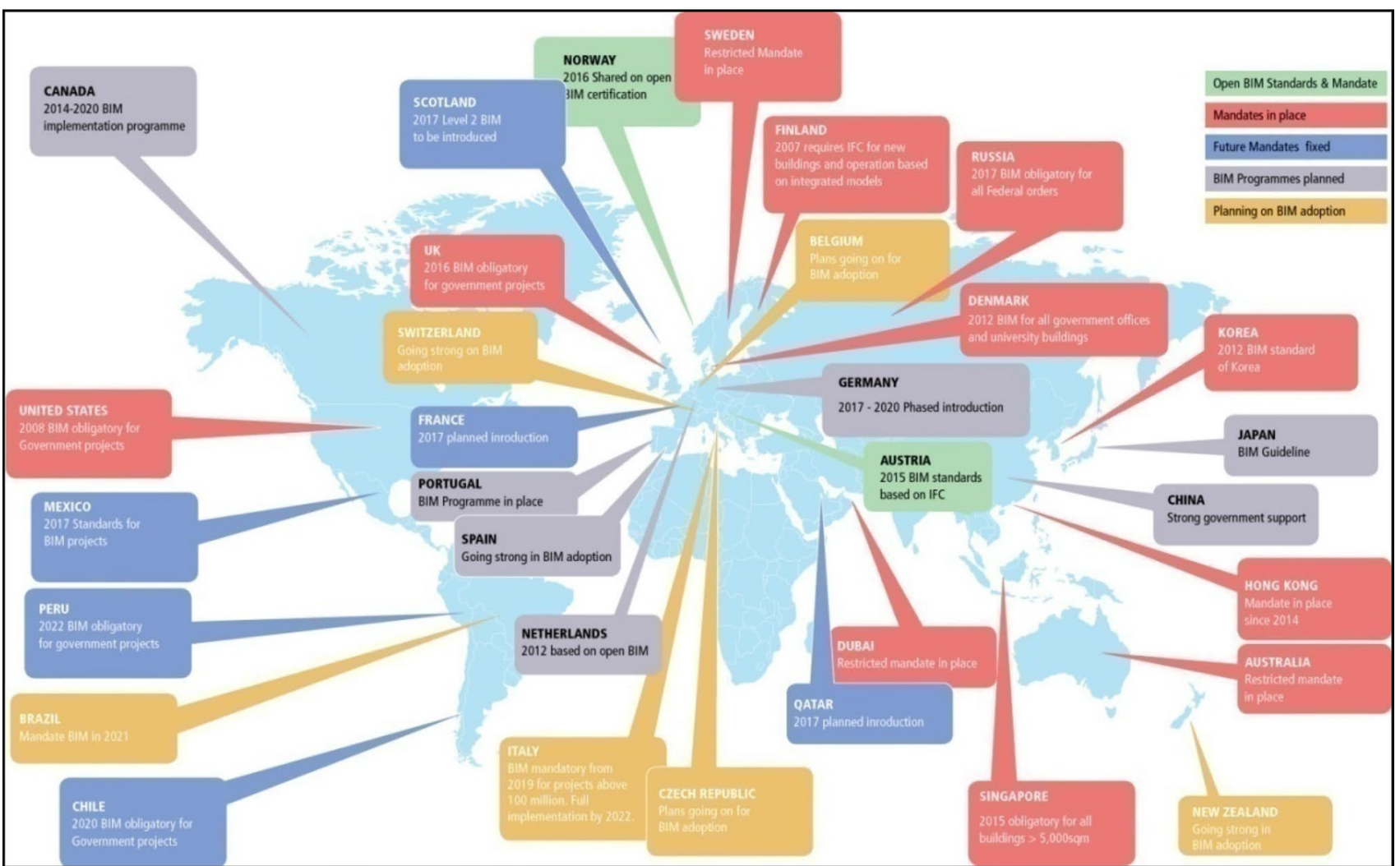

Fig. 3 Global trends of BIM adoption. Source: [44]

'over the wall' in a temporary "project organization" setting. The communication channels are often ad-hoc, leading to various versions of the 'truth' and an un-auditable trail of (in)decisions. These ineffective management practices invariably lead to disputes and delays and affect the reputation of the industry. The lifecycle perspective that BIM offers, along with its capability to document a single source of the truth', comes with a promise to alleviate some of the conventional inefficiencies. The benefits extend to site management practices too.

In construction site management, one of the most critical objectives is the safety of the site personnel. Most of the researchers identify safety as one of the major parameters affecting labour productivity [20,21].Construction processes in developing countries such as India involve labour-intensive operations, with very few contractors having the latest and advanced construction technologies available [22]. The Indian construction labour-power accounts for $7.5 \%$ of the overall world labor force, leading to $16.4 \%$ of the fatal global accidents at work. Occupational Safety and Health Administration (OSHA) estimated that every year one in ten construction site employees get injured. The OSHA also says falling hazards are the leading cause of injury at building sites. As per the article published by Indian Express in 2019, about 48,000 workers in India die from work-related accidents, 38 of which occur every day in the construction sector. According to the Bureau of Labor Statistics, around 150,000 injuries from construction sites occur every year. The minimum number of people who died annually in the construction sector in India between 2008 and 2012 was 11,614 [23]. Causes of accidents are identified in many kinds of research such as lack of PPE [24], poor safety training [25] and [26], negligence by contractors in safety management. The safety of labour is important as it creates a positive and healthy environment on-site and leads to an increase in overall productivity. However, safety is been given the least attention by management. Along with the other applications mentioned in the previous section, BIM can also be used for safety purposes [27]. The integration of BIM and safety can reduce the risks of accidents on-site [28]. Researches such as the integration of BIM and various technologies such as GIS, sensor technologies, unmanned aerial vehicles (UAVs) [29], safety planning of temporary structure [30], are observed for construction safety purposes. There is scope to adopt BIM for timely completion, increased productivity, and safety management. Although the focus of this study is on "BIM for safety" in the Indian construction industry, at first, the bibliographic search includes a broader global perspective so global initiatives in BIM for safety are identified and understood. As a result, the bibliometric 
data presented in this paper explores the adoption of BIM "globally" and then narrows down the search to the "local" context of Indian construction. The search is then further narrowed to include global "BIM for safety" trends followed by "BIM for safety in Indian construction". The survey is carried in two phases with different set of keywords (Sect. 3).In brief, the study focuses on adoption of BIM in construction industry in phase I and narrows down towards its applicability in the safety management in phase II.

\section{Methodology}

A bibliometric survey helps in understanding the worldwide published research with its publication year, country, author, journal of publication, affiliation on a single database. For this survey, Scopus database has been used for surveying the research in the selected domain. The survey has been carried out in two different phases with a selected set of keywords. These two phases unfold the worldwide adoption of BIM and also helps to understand Indian status for overall BIM adoption and safety in particular. Keywords play a significant role in the bibliometric survey as results vary with the small change in the keyword. The use of various conjunctions between keywords such as AND, OR also affects the results (Table 1).Phase I of the bibliometric survey has two parts, Part A and Part B. Part A represents the status of BIM adoption in the global construction industry and Part B represents the status of BIM adoption in the Indian construction industry. Basically, in phase I, global results observed in part A are limited to state India in part B.

Phase II of the survey is also divided into two parts, Part A and Part B. Part A of phase II represent the adoption of BIM for safety in global construction and part B of phase II represents the adoption of BIM for safety in the Indian construction industry. Basically, for both phases, I and II, search for global results are observed in part A and those results are limited to India in part B. Selected keywords for phase I consist of "BIM", "Building information modeling", and "Construction". Further, in part B (I) obtained results are limited for "India". For phase II, Selected keywords are "Building information modeling", "BIM", "Construction" and "Safety", further in part B (II), obtained results are limited towards "India". The methodology adopted for carrying out this bibliographic survey is shown in Fig. 4.
Figure 4 exhibits the process followed and the resulting documents from each phase of the bibliographic survey. The purpose of phase I is to understand the status of global BIM adoption. With the selected keywords of phase I, part A (Fig. 4), the search revealed a total of 6039 documents. Further, phase I results are limited in part B for "India" to study the quantum of research conducted in India. This search resulted in a total of 78 documents in India. After the result analysis of phase I, the survey moved towards phase II. Phase II has two parts, part A and part B. Phase II is carried out for analyzing the status of BIM adoption particularly for safety in the construction sector. Initially, for part A in phase II keywords selected are "BIM", "Building Information Modeling", "Construction", and "Safety". Part B of phase II represents the BIM adoption particularly for safety in the Indian construction sector. Part A of phase II shows a total of 549 documents globally, whereas, in part B, only 09 documents are observed for safety in Indian construction. Details of processes and statistics of these two phases are explained in Sects. 4 and 5.

\section{Phase I: Bibliometric Survey of BIM Adoption on Construction Sites}

Construction of any project involves various stages such as planning, designing, executing with coordination, for these stages BIM can be implemented. The bibliometric survey helps to understand the adoption of BIM at various construction stages globally. Phase I of the bibliometric survey has had two parts, Part A and Part B. Part A of phase I is about global BIM adoption in construction, and part B of phase I is about the adoption of BIM in Indian construction. Scopus revealed the results of 6039 documents globally for part A (I), starting from the year 1991 through mid of the year 2020. Documents appeared from countries such as the United States, China, United Kingdom, Germany, Australia, Canada, South Korea, Italy, Malaysia, Hongkong, Taiwan, Finland, and many more. Geographical attentiveness of 6039 documents of BIM adoption in the construction sector shows, a total of 96 different countries are involved globally (Fig. 5), out of which 286 documents are observed from undefined countries. The subsequent section describes the details of documents observed in the worldwide search.

Table 1 Keyword search criteria

\begin{tabular}{lll}
\hline Parts & Phase I (Overall BIM adoption) & Phase II (BIM adoption for safety) \\
\hline Part A (Global Construction) & "BIM" OR "Building Informa- & "BIM" OR "Building Information \\
& tion Modeling" AND "Con- & Modeling" AND "Construction" AND \\
& struction" & "Safety" \\
Part B (Indian construction) & Limiting results towards India & Limiting results towards India \\
\hline
\end{tabular}


Fig. 4 Methodology with many results obtained in each phase
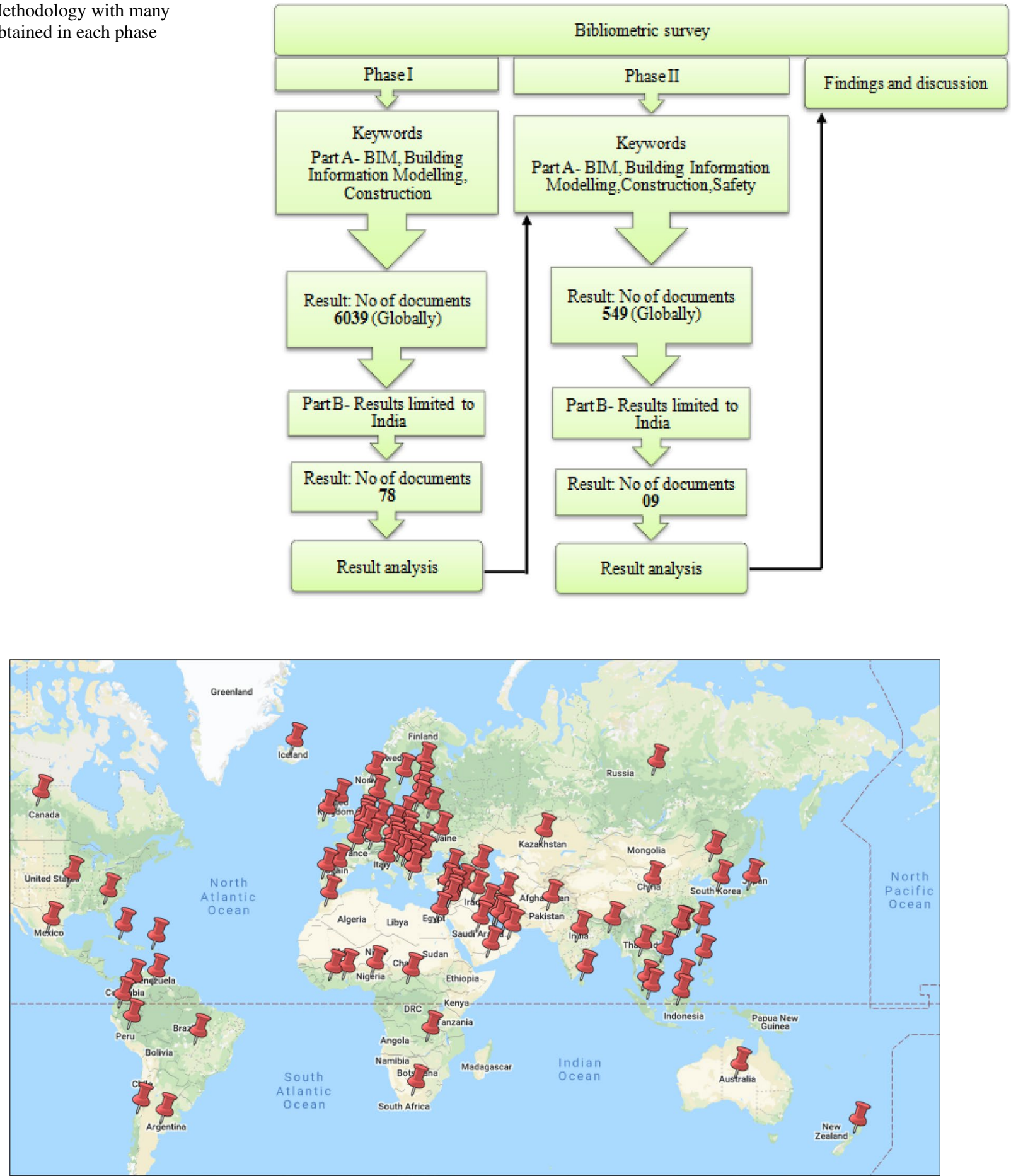

Fig. 5 Geographical location of BIM adoption in the construction sector globally-Phase I (Part A) (Prepared using iMapbuilder)

\subsection{Documents by Countries for Worldwide Search: Phase I (Part A)}

Among the 96 countries observed globally, countries with publications more than 50, are illustrated in Fig. 6. For part A of phase I, the top 5 countries having maximum documents published include, the United States of America (USA), China, United Kingdom (UK), Germany, and Australia. India is at the 17 th position out of a total of 50 countries. Of the total publications in the area of BIM, $19.10 \%$ documents are from the USA, $16.41 \%$ from China, and $10.74 \%$ from the UK with the year of publication beginning 
Fig. 6 Documents by global countries- Phase I (Part A) (Information source: www. scopus.com) [43]

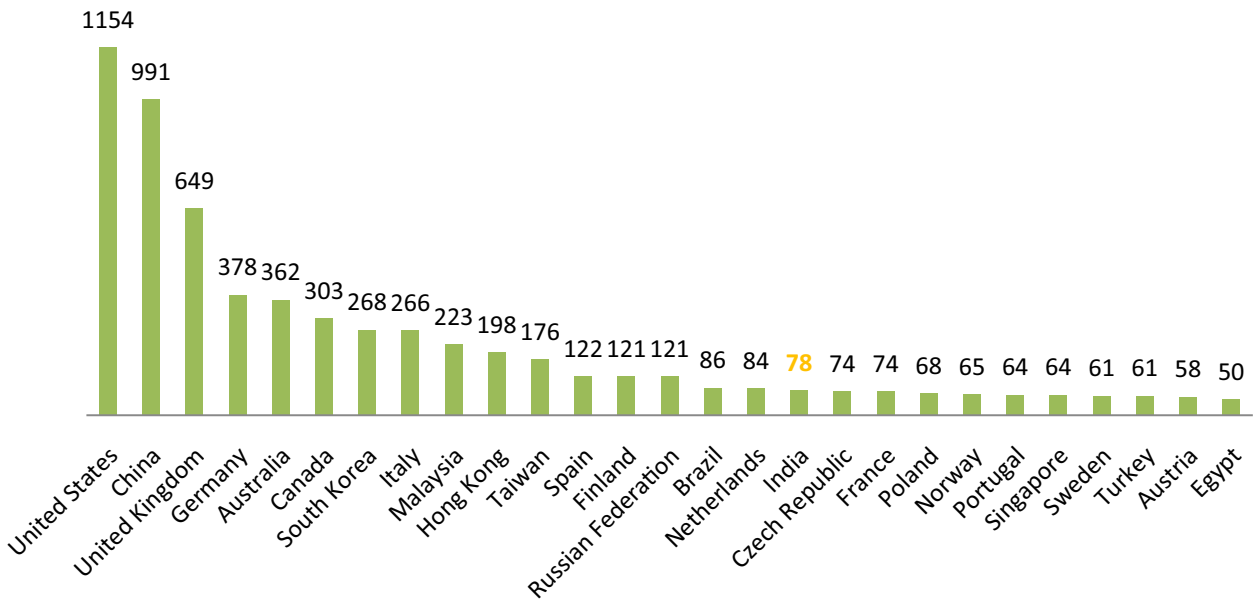

from 1991, proving the level of research in the area of BIM in these countries.

From its very beginning, the U.S. was the most rigorous in adopting and promoting BIM. It implemented BIM from the National University level to different levels of the public sector, resulting in BIM adaptations over the years [31]. Back in 2003, the US General Services Administration (GSA) set out the National 3D-4D-BIM system route. This program laid down policy mandating BIM adoption for all projects of the Public Buildings Service. BIM has become an important tool in the US Architecture, Engineering, and Construction (AEC) industry in recent years [32].

The 12th National Five-Year Plan (2011-2015) of China's Ministry of Housing and Urban-Rural Development claimed that industrialization, computerization, urbanization and agricultural modernization would be the main focus of the growth of their nation's building industry, with BIM technology playing a key role in each region [33]. The Tsinghua University of China has indicated that BIM will be China's future IT solution and the Chinese Government is strongly supporting BIM [34].

In April 2016, the UK government ordered to deliver all projects funded by the central government with 'complete collaborative 3D BIM.' As the law came into force, there was an increase in BIM adoption rates. BIM has been adopted by 20 percent of the industry since the mandate of 2016, according to the National BIM Report 2018. BIM is now a crucial factor for all larger organizations, and so this is now even shifting down on smaller organizations.

Indian construction industry is progressing slowly in implementing BIM due to various barriers to technology. Barriers such as mind-set issues, difficulties in adapting to frequent design changes, unavailability of specialist consultants and skilled resources, compatibility between software, high cost of hardware and software, unavailability of guidelines for process implementation, No government mandate for BIM implementation are prevalent [35]. Strong government support is one of the key factor for the growth and percolation of BIM in the fraternity, its long-lasting adoption, and continued research. However, the Indian government has adopted BIM in construction projects including personal rapid transit in Amritsar (in the year 2012), Bangalore Airport (2018), Nagpur Metro Rail (2017), Delhi Metro Rail (2018). As per the Ziguart Global Institute of Technology, architectural companies are the largest consumers of BIM on the Indian market. There needs to be a change in the main stakeholder mentality. Implementation of BIM has many benefits and a push for government mandate can positively impact the level of research, adoption, and implementation.

\subsection{Documents by Authors around the Globe- Phase I (Part A)}

Researchers play an important role in leading research and some have more prominence in a subject area than others. A total of 159 authors are involved globally in these 6039 publications. The top 10 global authors for phase I are listed in Fig. 7 in the descending order of the number of publications they have authored. However, this list does not consider the co-authorship between these publications. Some of these listed documents may be co-authored by authors appearing in the same list. In such cases, these common publications appear as individual documents for each author. For example, out of the 34 publications by Teizer and 40 publications by Konig, 07 documents are common and jointly co-authored by Teizer and Konig. Thus, seven common publications appear in search results (by the number of documents) of Teizer as well as Konig, as their individual publications. These authors have explored the adoption of BIM in different areas (some with the co-authorship). Issa, originally from the US, published maximum documents starting from the year 2009 to the year 2019. Publications by Issa include BIM adoption for several different areas. 


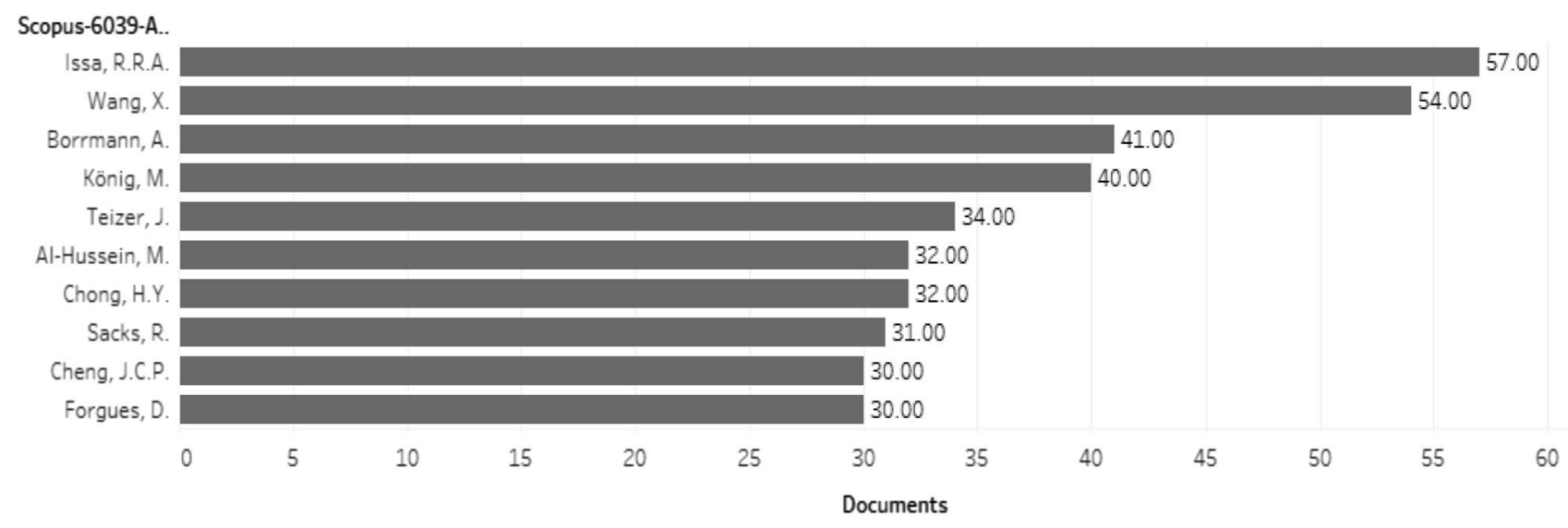

Fig. 7 Documents by global authors-Phase I (Part A) (Information source: www.scopus.com)

Some of the broader areas consist of BIM adoption for structural design, BIM for energy efficiency, Industry foundation classes, Radio Frequency Identification (RFID). Further, Wang (Australia) having the first publication in 2010, studied the area of visualization, augmented reality, sustainable development, and he recently published the joint-contract functions on BIM-enabled engineering procurement contract project and BIM and GIS integration in year 2020. Next, Borrmann (Germany), explored the area of BIM for information theory, photogrammetry, compliance control, knowledge-based systems with the publications year ranging from 2014 to 2020. Konig (Germany) has worked in the areas of BIM and robotics, BIM-based construction scheduling and off-site guarding in year staring from 2009 to 2020. Teizer (Germany) with his first publication in 2012, mainly focused on BIM adoption for safety. Areas such as BIM-enabled accident prevention, construction safety, BIM integrating with Global Positioning System (GPS) are researched by Teizer marking his last publication in this area in the year 2019.

Part B of Phase I represents status adoption of BIM for the Indian construction sector. The next section shows the analysis of documents' search result obtained for research in BIM in India.

\subsection{Documents by Year for India- Phase I (Part B)}

In India, about 340 million workers (92\%) are employed in unorganized sectors (plantation labour, handloom workers, fishermen, weavers, toddy tappers, beedi/local cigarettes workers) and about half are employed in the construction sector [36]. Management of this huge labour force with productive outcome majorly requires the use of the latest technologies in current construction practices. Considering BIM as a productive source for India, there was a need to find out its adoption year, fields of adoption, its adoption form, and the percentage of adoption in Indian construction. A line graph below shows yearly published documents in this field (Fig. 8) from the year 2010 to 2020.

It is observed that nineteen documents are published in the year 2019 and eighteen documents in the year 2018 respectively. The line graph reveals that from the last five years, the publications' count is increasing in the proposed domain.

\subsection{Documents by Indian Authors- Phase I (Part B)}

A total of 160 authors are involved in Indian research publications regarding BIM adoption. As explained in Sect. 3.1, some of the documents are published with co-authorship. Bar chart of the top 10 authors having maximum publications in this domain (Fig. 9) shows that Sawhney has the highest number of publications, followed by Varghese, Arif andAhuja.

Listed authors have conducted the research in different areas with BIM utilization (some with co-authorship). Sawhney with his first publication in the year 2011 (in this

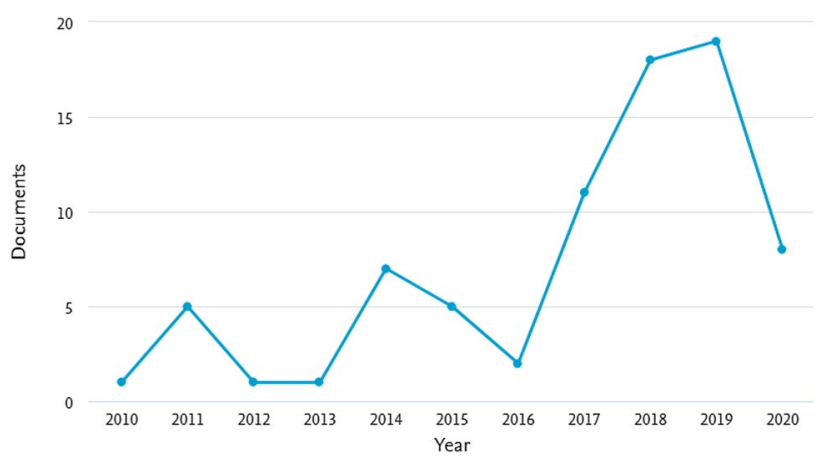

Fig. 8 Documents by year for India-Phase I (Part A) ( Source: www. scopus.com) 


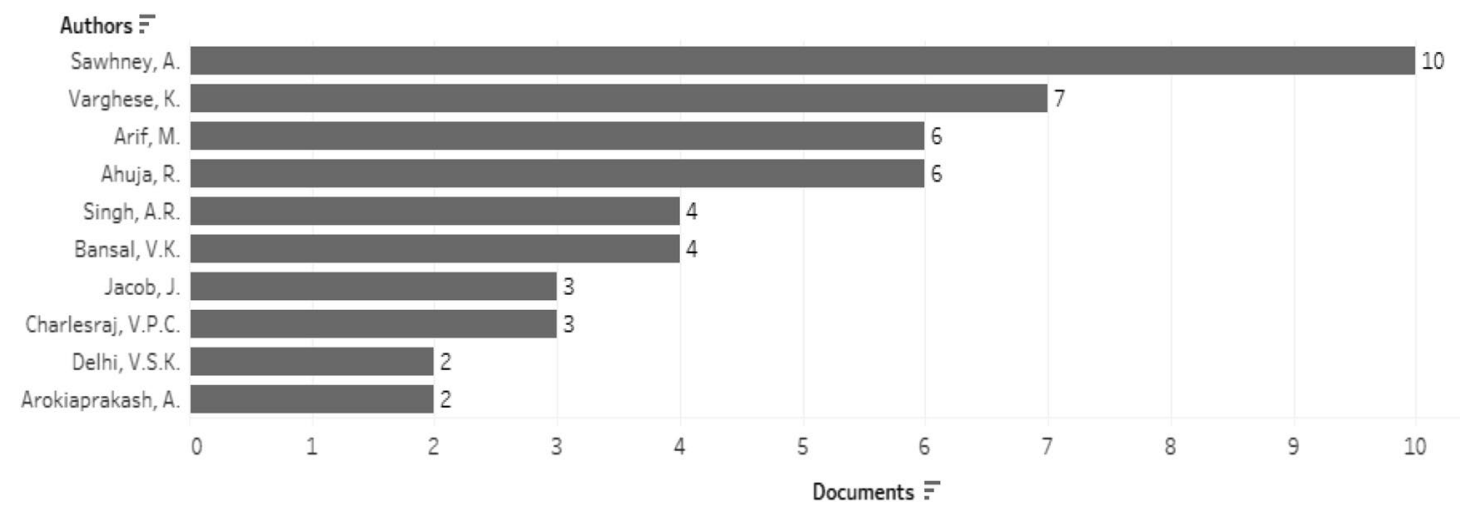

Fig. 9 Documents by an Indian authors- Phase I (Part B) (Information source: www.scopus.com)

domain), explored the areas such as lean and green project outcomes using BIM, parametric modeling for outside construction, interpretive structural modeling analysis, factors influencing BIM adoption in India, marking last publication in 2020. Varghese studied the integration of BIM and design structure matrix to improve design process, drivers and impediments of BIM from a social network perspective and BIM for precast construction between the years 2010 through 2018. Arif and Ahuja have researched an Indian case study questioning if BIM can furnish lean benefits, and published the outcomes from the year 2014 through 2020. Most of these areas are researched with co-authorship between these authors. Next author is Singh with his publication ranging from 2017 to 2019 , focusing on site layout planning using BIM. Next author is Bansal having first publication in 2011, and other 3 in 2020. He mainly emphasized on GIS implementation in construction scheduling, safety planning. As very few publications are observed in India, it could be due to lack of clear mandate for BIM adoption. Evidently, from the published works cited here, there are various examples of BIM projects in India. The thrust for BIM in India is rapidly gaining momentum, through NGOs such as
IBIMA(India Building Information Modeling Association) who are a leading professional national society for Building Information Modeling and Digitalization in Indian AECO sector (https://www.ibima.co.in/). IBIMA majorly focuses on BIM education and training; organizing BIM summits and events; BIM policy development; BIM maturity assessments and certifications. There is potential for Indian academics to actively engage with the activities led by IBIMA to further explore and understand the drivers, challenges, and opportunities for BIM adoption in India.

\subsection{Documents by Journals for Indian Publications- Phase I (Part B)}

Journals are the platforms for publishing research and are widely accessible over the internet. Papers published in peerreviewed journals are likely to remain a very critical way of communicating research findings. Journals having maximum publications, along with their country of origin and their $\mathrm{H}$-index are listed in Table 2.

'Journal of Procedia Engineering' has the most number of publications (six documents). 'Asian Journal of Civil

Table 2 Top 10 journals having maximum publications (Information Source: www.scopus.com)

\begin{tabular}{|c|c|c|c|}
\hline Journal name & $\begin{array}{l}\text { Number of docu- } \\
\text { ments }\end{array}$ & Country & H-index \\
\hline Procedia Engineering & 6 & Netherland & 51 \\
\hline Asian Journal of Civil Engineering & 5 & Iran & 16 \\
\hline International Journal of Civil Engineering and Technology & 4 & India & 18 \\
\hline Engineering Construction and Architectural Management & 3 & United Kingdom & 49 \\
\hline International Journal of Construction Management & 3 & United Kingdom & 14 \\
\hline International Journal of Recent Technology and Engineering & 3 & - & - \\
\hline International Journal of Engineering and Technology UAE & 2 & United Arab Emirates & 18 \\
\hline International Journal of Innovative Technology and Exploring Engineering & 2 & - & - \\
\hline Journal of Advanced Research in Dynamical and Control Systems & 2 & United States of America & 8 \\
\hline Journal of Construction Engineering and Management & 2 & United States of America & 95 \\
\hline
\end{tabular}


Engineering' is in the second position with five documents. Next is the 'International Journal of Civil Engineering and Technology' with four publications, followed by 'Engineering Construction and Architectural Management', 'International Journal of Construction Management' and 'International Journal of Recent Technology and Engineering' and others.

\subsection{Keyword Occurrences in Indian Public ations- Phase I (Part B)}

Keywords play an important role in bibliometric analysis. A network for keyword co-occurrence is prepared using tool VOSviewer. Figure 10 shows the occurrence of keywords in the selected domain. Keywords that appear with bigger font size are likely to have frequent occurrence as compared with keywords with lesser font sizes and the occurrence frequency can be quickly assessed by visual inspection of the changing font size.

As shown in Fig. 10, the 'architectural design' keyword has occurred 46 times among 77 documents. Followed by keyword 'building information modeling' with 25 occurrences. The third keyword is 'BIM' with 20 documents, followed by the 'construction industry' with a total 19 times of occurrences.

\section{Phase II: Bibliometric Survey for Adoption of BIM for Safety on Construction Sites}

The construction industry is highly exposed to accidents. On-site accidents can cause serious injuries or may cause the death of labour. Safety is one of the crucial factors for productivity improvement; it's still highly ignored area by the organization. Phase II of bibliometric survey is carried for
BIM adoption in construction, especially for 'safety'. Phase II is also divided into two parts part A and part B, part A of phase II represents the global adoption of BIM for safety and part B of phase II represents the adoption of BIM for safety in 'Indian' construction. Keywords selected for part A (II) are 'BIM', ' building information modeling', 'construction' and safety'. Part A with a selected set of keywords resulted in a total of 549 documents globally. Part B of phase II regarding BIM adoption for safety in Indian construction revealed a total nine documents. Following section explains the results of Part A and Part B of phase II.

\subsection{Documents by Year Globally- Phase II (Part A)}

The year of the research publication helps to know it's when the particular research is done in a particular area as well as years increase or decrease in that particular field. Part A (II) with selected keywords revealed total of549 documents globally. Line graph of year-wise published documents for part A (Fig. 11) states that a total of 549 documents published starting from the year 2006 upto mid-2020, out of which highest number of documents with 105 counts are published in the year 2019. The second is 2018 with 91 documents.

From year 2006 to 2019, there is a consecutive increase in the number of documents. A total of 38 documents are observed until midyear 2020. The rising line in the graph shows that researches are increasing in this domain all over the world.

\subsection{Documents by Countries- Phase II (Part A)}

Construction safety is one of the most important aspects of construction industry. Safety management is equally important worldwide, as it can cause hazards, injuries.
Fig. 10 Network showing the co-occurrence of keywords using VOSviewer-Phase I(Part B) 4d modelling

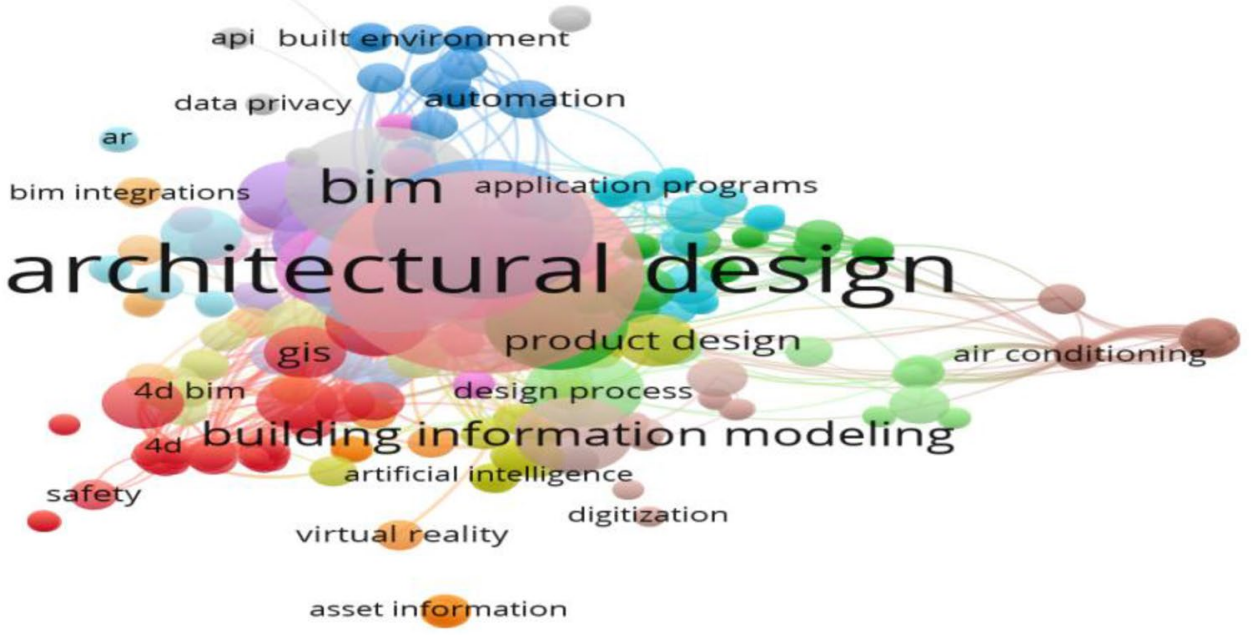




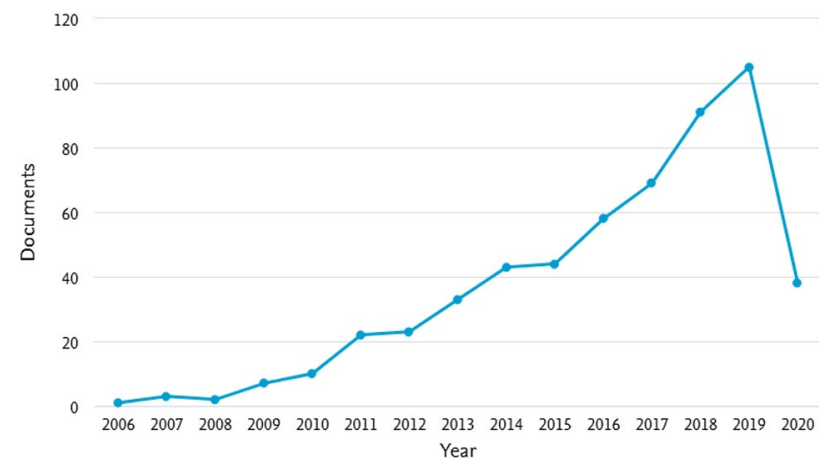

Fig. 11 Year-wise publications globally- Phase II (Part A) ( sourcewww.scopus.com)

International Labor Organization (ILO) found that 2.8 millions of worker deaths are reported worldwide each year, with over 6,500 deaths from work-related diseases every day and 1,000 from work-related accidents. Unfortunately, construction workers are not completely immune to these risks. Safety is the prime responsibility of all who are involved in the construction project.
Studying the statistics of global BIM adoption for safety helps to understand the countries with most publications in the BIM topic area, indicative of BIM research. A total of 549 documents are published in 58 countries, out of which, 42 documents are from undefined countries. The bar chart in Fig. 12 shows the top 15 countries having maximum publications globally. The US is again leading with 128 number of publications. Second is China with 113 number of documents.

Further, the United Kingdom has 47 documents. India has 9 documents in BIM, particularly in safety. Evidently, the adoption of BIM for safety is still in the embryonic state. There is clearly a need for more initiatives in the field of BIM adoption, particularly for construction safety, if the challenges cited earlier are to be addressed. This analysis also emphasizes on the scope of research in this domain. Many countries have researched in the area of BIM for safety management (Fig. 13). In the USA they have utilized BIM in all the construction processes, it is not restricted to design and planning. For safety management researches such as development of an automated models using BIM and safety [27], BIM-based fall hazard identification [37], BIM-based

Fig. 12 Documents by global countries-Phase II (Part A) (Information source-www. scopus.com)
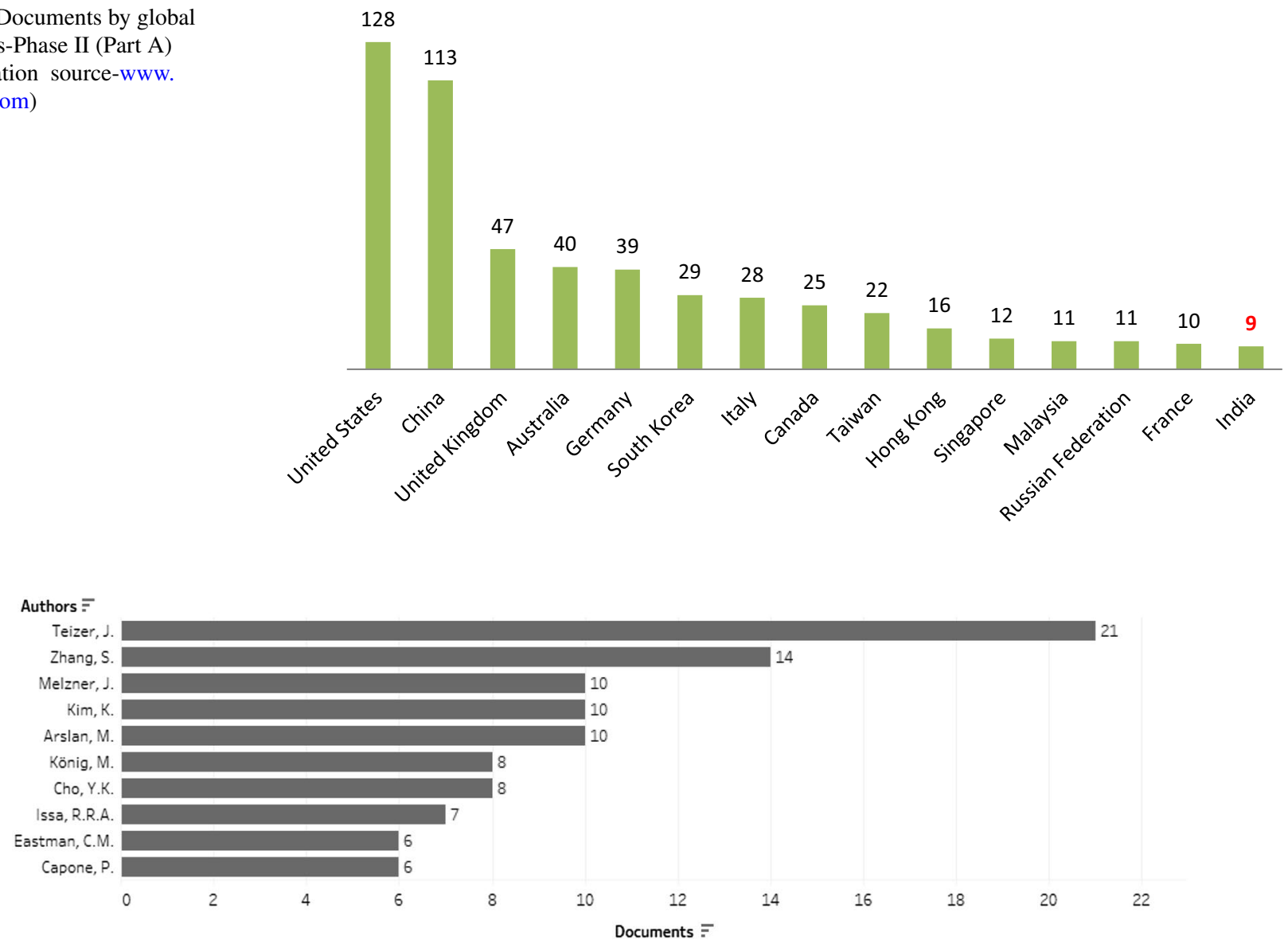

Fig. 13 Documents by global authors-Phase II (Part A) (Information source: www.scopus.com) 
automated scaffolding [38] are carried out. China is also one of the largest construction industry and have developed models for safety using BIM. Areas such as BIM-based risk identification [39], accident prevention through design [40] are explored. Construction industry in the UK have also adopted BIM for various safety purposes, such as energy-efficient buildings [41], construction health and safety [42]. Almost in all construction activities, BIM has been utilized and most of them have benefited from using BIM. Considering India, first BIM research publication is observed in the year 2010 and BIM adoption for safety in year 2011. Studies in this field are initiated since decade. Accident rates on Indian construction sites are still increasing and current safety management methods are insufficient. Only nine documents for BIM implementation in safety invites attention to the fact that the majority of the BIM uses are limited to design and engineering in India. The awareness level of BIM in India in 2017 was 20 percent, and it needs to be increased [32].

\subsection{Documents by Authors across the Globe- Phase II (Part A)}

A total of 160 authors are involved in search of part A (II) globally. Figure 13 illustrates the top 10 authors in this area with the maximum number of publications. Some authors have publications with co-authorship. Teizer has 21 number of documents followed by Zhang with 14 documents.

Teizer (Germany) is at the fifth position in the list of global authors for BIM adoption (2012-2019) and on 1st position in list of global authors for BIM adoption in safety (2012-2019). Safety management such as rule-based model checking, heat map generation for predictive safety planning, RFID and BIM-enabled worker location tracking, BIM-based fall hazard identification, automatic safety checking of construction model, and schedules are explored by Teizer. Zhang (US) with first publication in 2012, studied the areas such as automated scaffolding safety hazards identification and prevention, GPS to model the workspaces density in construction safety planning marking last publication in 2016. Melzaner (Germany), starting from year 2012 till 2019, emphasized on the areas such as multi-criteria decision-support approach for fall protection, object-oriented safety risk simulation. Kim (US) explored the BIMbased decision support system that provides safety plans for temporary structures, optimization of scaffolding plans for safety ranging from year 2014 to 2019. Arslan (France) with his publications ranging from year 2014 to 2020, focused on intrusions in dynamic building environments for worker safety, BIM, and sensor-based data management for construction safety. Following section discusses the analysis of documents observed for BIM adoption in safety in India. For this part B of phase II, 9 documents revealed for India, are analyzed.

\subsection{Documents by Year for India- Phase II(Part B)}

Research in the field of BIM adoption for safety in India is observed from the year 2011 to 2019 (Fig. 14). Two documents are published in each of the year 2011, 2018, and 2019. One document is observed in mid-year 2020.

Details of these nine publications are tabulated (Table 3) with details including title of the document, author, year of publication, source of publication, and citation. Among those listed, it is evident that the research has been for BIM for site layout planning, BIM and GIS integration for site safety and for formwork systems. It is observed that the work in the area of BIM adoption for safety is relatively limited.

\section{Summary of Phase I and Phase II}

Table 4 summarizes the bibliographic survey results of the phase I and phase II search. It includes total number of documents that appeared phase-wise and part-wise, top three countries with maximum number of documents published, and top three authors with number of publications in the bracket. Part B in each phase indicates India's position relative to the top 3 listed countries and lists the authors with the most published work in that phase of the study.

\section{Findings and Discussion}

This paper is a part of a wider research study that focuses on "BIM for safety" in the Indian construction industry. The early stage of this research has thus, primarily focused on identifying the global trends of BIM adoption in the construction sector and then narrowing the focus on its adoption for safety purposes. This helped to identify, which countries are dominant in this research area, what their focus of research has been on, and who the most prominent authors have been. To narrow the focus from BIM globally to BIM

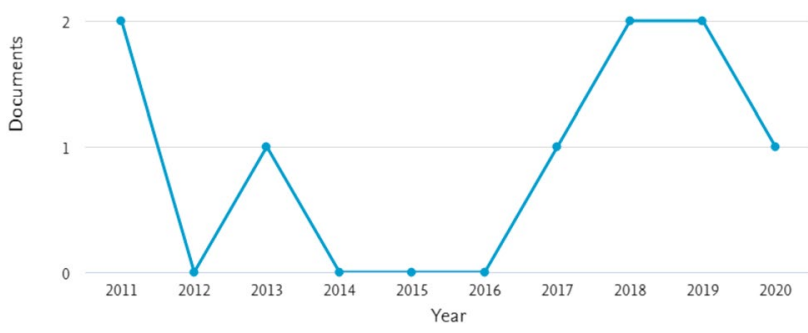

Fig. 14 Documents by year for India-Phase II (Part A) ( source: www.scopus.com) 
Table 3 Details of the ten most recently published documents (Information source: www.scopus.com)

\begin{tabular}{|c|c|c|c|c|}
\hline Title & Authors & Year & Source title & Cited by \\
\hline $\begin{array}{l}\text { Application of geographic information } \\
\text { systems in construction safety planning }\end{array}$ & Bansal V.K & 2011 & $\begin{array}{l}\text { International Journal of Project Manage- } \\
\text { ment }\end{array}$ & 93 \\
\hline $\begin{array}{l}\text { Constructability assessment of climbing } \\
\text { formwork systems using building infor- } \\
\text { mation modeling }\end{array}$ & Ramesh Kannan M., Helen Santhi M & 2013 & Procedia Engineering & 21 \\
\hline $\begin{array}{l}\text { Construction projects scheduling using GIS } \\
\text { tools }\end{array}$ & Bansal V.K., Pal M & 2011 & $\begin{array}{l}\text { International Journal of Construction } \\
\text { Management }\end{array}$ & 10 \\
\hline $\begin{array}{l}\text { Parametric Modeling for Designing Offsite } \\
\text { Construction }\end{array}$ & Sharma S., Sawhney A., Arif M & 2017 & Procedia Engineering & 7 \\
\hline $\begin{array}{l}\text { Automated constructability rating frame- } \\
\text { work for concrete formwork systems } \\
\text { using building information modeling }\end{array}$ & Kannan M.R., Santhi M.H & 2018 & Asian Journal of Civil Engineering & 3 \\
\hline $\begin{array}{l}\text { Site layout planning through BIM visuali- } \\
\text { zation-A case study }\end{array}$ & Lota P.S., Trivedi J & 2020 & $\begin{array}{l}\text { 27th Annual Conference of the Interna- } \\
\text { tional Group for Lean Construction, } \\
\text { IGLC } 2019\end{array}$ & 0 \\
\hline $\begin{array}{l}\text { Changi water reclamation plant: The plant } \\
\text { of the future constructed in the now }\end{array}$ & Brice R., Dalasung E., Joshi S & 2019 & $\begin{array}{l}\text { WEFTEC 2019—92nd Annual Water } \\
\text { Environment Federation's Technical } \\
\text { Exhibition and Conference }\end{array}$ & 0 \\
\hline $\begin{array}{l}\text { Optimizing site layout planning utilizing } \\
\text { building information modeling }\end{array}$ & Singh A.R., Patil Y., Delhi V.S.K & 2019 & $\begin{array}{l}\text { Proceedings of the 36th International } \\
\text { Symposium on Automation and Robotics } \\
\text { in Construction, ISARC } 2019\end{array}$ & 0 \\
\hline $\begin{array}{l}\text { A study on the potential of big visual data } \\
\text { analytics in the construction arena }\end{array}$ & $\begin{array}{l}\text { Bhargava M.G., Vidyullatha P., Ven- } \\
\text { kateswara Rao P., Sucharita V }\end{array}$ & 2018 & $\begin{array}{l}\text { International Journal of Engineering and } \\
\text { Technology(UAE) }\end{array}$ & 0 \\
\hline
\end{tabular}

Table 4 Summary of phase I and phase II

\begin{tabular}{|c|c|c|c|c|}
\hline & \multicolumn{2}{|l|}{ Phase I } & \multicolumn{2}{|l|}{ Phase II } \\
\hline & Part A & Part B & Part A & Part B \\
\hline Total Documents & 6039 & 78 & 549 & 09 \\
\hline Top 3 Countries & $\begin{array}{l}\text { US } \\
\text { China } \\
\text { UK }\end{array}$ & India at 17 th position & $\begin{array}{l}\text { US } \\
\text { China } \\
\text { UK }\end{array}$ & India at 15 th position \\
\hline Top 3 Authors & $\begin{array}{l}\text { Issa (57) } \\
\text { Wang (54) } \\
\text { Borrmann (41) }\end{array}$ & $\begin{array}{l}\text { Sawhney (10) } \\
\text { Varghese (07) } \\
\text { Ahuja and Arif (06) }\end{array}$ & $\begin{array}{l}\text { Teizer (21) } \\
\text { Zhang (14) } \\
\text { Alsar, Kim and } \\
\text { Melzner (10) }\end{array}$ & $\begin{array}{l}\text { Bansal }(02) \\
\text { (Remaining all authors } \\
\text { have } 01 \text { publication } \\
\text { each) }\end{array}$ \\
\hline
\end{tabular}

locally (India) and then from BIM for safety globally to BIM for safety locally, a phased approach was adopted. For ease of understanding, bibliometric survey has been carried out in two different phases, Phase I and Phase II. Part A of the phase I explored the global adoption of BIM and part B of phase I explored BIM adoption in India. In phase II, part A explored global BIM adoption for safety and part B explored BIM adoption for safety in India. Phase I search revealed that total of 6039 documents are published on BIM adoption in the construction sector all over the world. Further, these results were limited to India in part B of phase I and were observed that out of all documents only $1.29 \%$ of documents, i.e., 78 documents were from India.

The construction industry is largely exposed to various hazards due to a number of uncertainties in its operation, the site conditions, and use of heavy machinery. Effective site safety management is the necessity of any construction site, as it can reduce the rate of accidents on site. Thus, the survey was carried out in phase II for assessing the level of the adoption of BIM for safety on construction sites. This second phase, with selected keywords, revealed that only 549 documents are published till date globally. Out of which only nine documents are from India. The findings of this survey have aided in understanding that the adoption of BIM in India, is still at the embryonic stage. Clearly, there are some notable BIM 'champions' who have initiated BIM research in India. There is much to be learned from such initiatives (globally and locally) to aid the understanding of the drivers, the challenges, and the opportunities for BIM adoption. Given that the body of knowledge in BIM for safety in India has at its best been 
scant, there is a huge opportunity for researching into the adoption of BIM for safety in Indian construction industry.

Countries such as USA, China, UK are evidently leading in BIM utilization, being early adopters of BIM. India on the other hand, has been relatively slow in its adoption. The first of the research publications in the domain of BIM has been in 2011. Most active Indian authors identified in the field of BIM adoption in the Indian construction are Sawhney, Varghese, Ahuja, and Arif. Bansal has been proactively involved in pioneering research in the domain of BIM adoption in India for safety. Work of these researchers is observed in the area of BIM implementation for parametric modeling, design process, BIM, and GIS for safety planning. It is also witnessed that majority of the studies in India have been limited to examining the barriers to or challenges for BIM adoption, and not necessarily on its implementation. This is indicative of the early stages of adoption. In countries that are leading in BIM adoption, much of the thrust has come from the government mandating its adoption. This has accelerated the adoption of BIM in these countries. No such mandate exists in India. That isn't to say that its importance hasn't been recognized. NGOs such as IBIMA, are committed to raising BIM awareness and developing a critical mass of projects and activities aimed at giving BIM the podium it deserves. IBIMA with its membership spread globally and nationally, has been a major force for pushing the BIM agenda and has contributed towards the digitalization in the Indian AECO-sector. BIM has potential to reduce the cost overrun, time overrun, and to provide a quality outcome. Along with the application of digital representation of the structure, scheduling, clash detection, quantity takeoff, BIM, with its visualization capability could help identify common hazards and the risks they present. This could help contractors, labours to take preventive measures, and minimize or manage the hazards effectively. Given that BIM adoption in India is still in its infancy, it has not been used in Indian construction for safety purposes. BIM has the potential to gain noteworthy benefits for the Indian construction industry. It is gradually gaining acceptance from the owners, architects, engineers, and builders. More needs to be done to raise awareness and accelerate its adoption. Successful implementation of $\mathrm{BIM}$ requires a transformation in the process and practice of all involved stakeholders. It is important to comprehend that BIM, is not just software, but a process where all the stakeholders ultimately come together and manage construction processes effectively and efficiently. Only then can its benefits be truly realized.

Funding None.

\section{Declaration}

Conflict of interest On behalf of all authors, the corresponding author states that the authors have no conflict of interest.

Open Access This article is licensed under a Creative Commons Attribution 4.0 International License, which permits use, sharing, adaptation, distribution and reproduction in any medium or format, as long as you give appropriate credit to the original author(s) and the source, provide a link to the Creative Commons licence, and indicate if changes were made. The images or other third party material in this article are included in the article's Creative Commons licence, unless indicated otherwise in a credit line to the material. If material is not included in the article's Creative Commons licence and your intended use is not permitted by statutory regulation or exceeds the permitted use, you will need to obtain permission directly from the copyright holder. To view a copy of this licence, visit http://creativecommons.org/licenses/by/4.0/.

\section{References}

1. Planning Commission Government of India (2013) Twelfth five year plan (2012-2017) social sectors, Volume III. http://nhm.gov. in/images/pdf/publication/Planning_Commission/12th_Five_ year_plan-Vol-3.pdf

2. Azhar S, Khalfan M, Maqsood T (2012) Building information modeling (BIM): now and beyond. Australas J Constr Econ Build 12(4):15-28

3. Shou W, Wang J, Wang X, Chong HY (2015) A comparative review of building information modelling implementation in building and infrastructure industries. Arch Comput Methods Eng 22(2):291-308

4. Gerrish T, Ruikar K, Cook M, Johnson M, Phillip M, Lowry C (2017) BIM application to building energy performance visualisation and management challenges and potential. Energy Build 144:218-228

5. Azhar S (2011) Building information model (BIM): trends, benefits, risks, challenges AEC industry. Lead Manag Eng 11(3):241-252

6. Monyane TG, Ramabodu MS (2014) Exploration of Building Information Modelling (BIM) concept and its effects on quantity surveying profession in South Africa: case of FS Province. In: 7th Annu. SACQSP Res. Conf. "Mapping Futur., no. March. pp 419-429

7. Bouška R (2016) Evaluation of maturity of BIM tools across different software platforms. Procedia Eng 164(June):481-486

8. Azhar S, Carlton WA, Olsen D, Ahmad I (2011) Building information modeling for sustainable design and LEED $(\mathbb{B}$ rating analysis. Autom Constr 20(2):217-224

9. Pezeshki Z, Ivari SAS (2018) Applications of BIM: a brief review and future outline. Arch Comput Methods Eng 25(2):273-312

10. Tahir MM, Haron NA, Alias AH, Al-Jumaa AT, Muhammad IB, Harun AN (2018) Applications of building information model (BIM) in Malaysian construction industry. IOP Conf Ser Mater Sci Eng 291(1):012009

11. Eadie R, Odeyinka H, Browne M, McKeown C, Yohanis M (2013) An analysis of the drivers for adopting building information modelling. J Inf Technol Constr 18:338-352

12. Bongiorno N, Bosurgi G, Carbone F, Pellegrino O, Sollazzo G (2019) Potentialities of a highway alignment optimization method in an i-bim environment. Period Polytech Civ Eng 63(2):352-361

13. Vigneault MA, Boton C, Chong HY, Cooper-Cooke B (2020) An innovative framework of 5D BIM solutions for construction cost 
management: a systematic review. Arch Comput Methods Eng 27(4):1013-1030

14. Caetano I, Leitão A (2019) Integration of an algorithmic BIM approach in a traditional architecture studio. J Comput Des Eng 6(3):327-336

15. Zanni MA, Soetanto R, Ruikar K (2017) Towards a BIM-enabled sustainable building design process: roles, responsibilities, and requirements. Archit Eng Des Manag 13(2):101-129

16. Ahuja R, Jain M, Sawhney A, Arif M (2016) Adoption of BIM by architectural firms in India: technology-organization-environment perspective. Archit Eng Des Manag 12(4):311-330

17. Succar B, Kassem M (2016) Building information modelling: point of adoption. CIB World Congress, Tampere Finland. In: CIB World Conference Proceedings, vol 1

18. Hamma-adama M, Kouider T (2019) Comparative analysis of BIM adoption efforts by developed countries as precedent for new adopter countries. Curr J Appl Sci Technol. https://doi.org/ 10.9734/cjast/2019/v36i230224

19. Zima K, Plebankiewicz E, Wieczorek D (2020) A SWOT analysis of the use of BIM technology in the polish construction industry. Buildings 10(1):16

20. Hai DT, Van Tam N (2019) Analysis of affected factors on construction productivity in Vietnam. Int J Civ Eng Technol 10(2):854-864

21. Kazaz A, Ulubeyli S, Acikara T, Er B (2016) Factors affecting labor productivity: perspectives of craft workers. Procedia Eng 164(June):28-34

22. Auti A, Skitmore M (2008) Construction project management in India. Int J Constr Manag8(2): 65-77

23. Patel DA, Jha KN (2016) An estimate of fatal accidents in Indian construction. In: Proceedings 32nd annual ARCOM conference ARCOM 2016, September. pp 539-548

24. Ahmed S (2019) Causes of accident at construction sites in Bangladesh. Org Technol Manag Constr Int J 11(1):1933-1951

25. Kanchana S, Sivaprakash P, Joseph S (2015) Studies on labour safety in construction sites. Sci World J 2015:1-6

26. Bhole MAS (2016) Safety problems and injuries on construction site: a review. Int. J. Eng. Tech 2(4):24-35

27. Zhang S, Teizer J, Lee JK, Eastman CM, Venugopal M (2013) Building information modeling (BIM) and safety: automatic safety checking of construction models and schedules. Autom Constr 29:183-195

28. Hossain MM, Ahmed S (2019) Developing an automated safety checking system using BIM: a case study in the Bangladeshi construction industry. Int J Constr Manag. https://doi.org/10.1080/ 15623599.2019.1686833

29. Alizadehsalehi S, Yitmen I, Celik T, Arditi D (2018) The effectiveness of an integrated BIM/UAV model in managing safety on construction sites. Int J Occup Saf Ergon 26(1):829-844

30. Kim K, Cho Y, Kim K (2018) BIM-driven automated decision support system for safety planning of temporary structures. J Constr Eng Manag 144(8):1-11
31. Amarnath CB (2019) BIM implementation in India. India Building Information Modelling Association (R .), pp 1-10. https:// www.ibima.co.in/post/bim-implementation-in-india

32. Shimonti P (2018) BIM adoption around the world: how good are we? Geospatial World, pp 1-12 https://www.geospatialworld.net/ article/bim-adoption-around-the-world-how-good-are-we/

33. Ji B, Qi Z, Jin Z (2014) The obstacles and strategy of building information modeling application in Chinese construction industry. Int J Comput Theory Eng 6(6):504-509

34. Hore A, McAuley B, West R (2017) BICP Global BIM Study: Lessons for Ireland's BIM Programme. Constr. IT Alliance (CitA) Limited, 2017. https://doi.org/10.21427/D7M049

35. Sawhney A (2014) State of BIM Adoption and Outlook in India. RICS Res., no. May. pp 1-30. http://www.fig.net/resources/proce edings/fig_proceedings/fig2014/ppt/ss36/ss36_kavanagh_7434. pdf

36. Tiwary G et al (2012) Socio-economic status of workers of building construction industry. Indian J Occup Environ Med 16(2):66-71

37. Zhang S, Sulankivi K, Kiviniemi M, Romo I, Eastman CM, Teizer J (2015) BIM-based fall hazard identification and prevention in construction safety planning. Saf Sci 72:31-45

38. Kim K, Cho Y, Zhang S (2016) Integrating work sequences and temporary structures into safety planning: automated scaffoldingrelated safety hazard identification and prevention in BIM. Autom Constr 70:128-142

39. Zhang L, Wu X, Ding L, Skibniewski MJ, Lu Y (2016) Bim-based risk identification system in tunnel construction. J Civ Eng Manag 22(4):529-539

40. Yuan J, Li X, Xiahou X, Tymvios N, Zhou Z, Li Q (2019) Accident prevention through design (PtD): integration of building information modeling and PtD knowledge base. Autom Constr 102(February):86-104

41. Eleftheriadis S, Mumovic D, Greening P (2017) Life cycle energy efficiency in building structures: a review of current developments and future outlooks based on BIM capabilities. Renew Sustain Energy Rev 67:811-825

42. Muzafar M (2020) Building information modelling to mitigate the health and safety risks associated with the construction industry: a review. Int J Occup Saf Ergon. https://doi.org/10.1080/10803548. 2019.1689719

43. Bibliometric data accessed from scopus database in June 2020. https://www.scopus.com/sources?zone $=$ TopNavBar\&origin $=$ NO\%20ORIGIN\%20DEFINED

44. URL 1: https://www.geospatialworld.net/article/bim-adopt ion-around-the-world-how-good-are-we/

Publisher's Note Springer Nature remains neutral with regard to jurisdictional claims in published maps and institutional affiliations. 